\title{
Integrating Marine Transport with Other Public Transport Modes in Dubai
}

\author{
Akmal Abdelfatah, Farida Nasser \\ American University of Sharjah \\ P.O. Box 26666, Sharjah, UAE \\ Akmal@aus.edu; g00028323@aus.edu
}

\begin{abstract}
This paper discusses the proposed approach for the development of a procedure to provide integration between Marine Stations and different transportation modes in Dubai. Five case studies of existing and proposed marine stations were conducted in order to reach an integration scheme for each one of them. The considered stations contain a mix of different marine transportation modes' stations, located on both sides of Dubai's Creek, tourist and commuter routes, and different land uses surrounding the stations. The case studies results have been used in order to suggest a procedure to be followed and integration items for the overall system of marine transport. A priority list has been proposed to assist decision makers to choose the most effective integration component according to budget availability.

It is clearly observed that the best way to achieve integration is to build a multimodal transportation station (transportation hub), however, this approach should be adopted in the early planning stages starting with the Master Plan stage thus it can't be adopted in case of existing stations. In addition, in some cases it is difficult to build multimodal stations to achieve integration within marine modes due to the limitation of locating marine stations to the shoreline and along the waterways, while Metro lines are rigid and not easy to be adjusted. Air-conditioned bridges and tunnels are used to make the walking environment more convenient for pedestrian to walk between different stations. Pedestrian flow and safety are the main items to identify/justify the suggested integration components to insure the cost effectiveness of the solution, however there are other items addressed in the study to prioritize the implementation of suggested solutions through quantitative method.
\end{abstract}

Keywords: Marine Transportation, Public Transportation, Integrating Transport Modes, Multimodal Travel.

\section{Introduction}

Most of the major cities in the Gulf region have experienced very high rates of growth over the past decade. Dubai is becoming larger and larger with high growth rate due to policies, innovative projects, and ideas implemented in the city. The growth rate of the city is one of the highest in the world, which is related to the high immigration rate rather than fertility rate, thus the city has become the Middle East main business center. On the other hand, the city becomes one of the famous cities for tourist attraction where millions are coming each year, especially during the festivals. In order to provide appropriate services for the increasing population, new businesses investments, and huge projects were announced and started the construction. Some of these huge innovative developments can stand alone as cities.

In order to continue the success story, Dubai paid attention to providing the appropriate infrastructure, where transportation is one of the most important items. Since the city started its growth in 1971 by the announcement of the Emirates Union, the city was depending heavily on road system for transportation. More than $95 \%$ of the trips within the city are using private cars, while the system of Public Buses which uses the same road network was carrying only $3 \%$ of trips, with the remaining $2 \%$ for company buses, school buses, abras, walking, ..etc (these percentages were counted before Dubai Metro lunching in September, 09, 2009 [1]. Automobile ownership and population income have more influence on car share here than the density of land uses as in Lisbon metropolitan area [2]. Since the increase in road network capacity (supply) was not matching the increase in the population (demand), and the city was expanding in all dimensions, therefore the trips became longer, and road congestion started to appear. At the same time, planners expected that a real congestion and air pollution problem may appear if there were no major changes in the travel mode.

To avoid these problems, public transit systems became a must in order to provide new, modern, reliable, high quality, accessible transit system. 
As part of the institutional integration, Dubai government established the Dubai Road and Transport Authority (RTA), as a governmental agency responsible for developing and implementing transportation plans in order to provide safe and smooth movement in Dubai. The RTA has introduced 5 agencies which are: Traffic and Road Agency, Rail Agency, Marine Agency, Public Buses Agency, and Dubai Taxi Agency to cover all transportation fields and to implement the recent and reliable best technologies in transportation. Each agency is responsible for a group of transportation modes.

For Public Transport system, to be successfully operated and to achieve an efficient use and cost, they should be: 1) well integrated, 2) completing each other and not competing, 3) providing comparable level of service (LoS), 4) and having a comprehensive fare collection system.

The integration of different transportation modes is one of the most important items to guarantee the success of the public transportation systems. Thus having each system covering the whole city and providing accessibility to each destination in addition to mobility will need huge infrastructure which is very expensive, land consuming, difficult to be achieved technically, and the systems will be underutilized.

RTA has noticed the importance of integration between different modes, so attention has been paid in early stages, and many studies have been conducted to study the accessibility and connectivity between different modes of transport. This work will focus on the hard integration of the marine transportation with other modes.

\section{Literature Review}

In developed cities; a comprehensive plan is a must because of the importance of planning for the city growth and development, this saves money and protects the resources. A comprehensive plan has many items and needs many studies and data in order to be completed. However; infrastructure is one of the most important items. Among the infrastructure, the transportation sector has the most attention and in most cases consumes a large portion of city's budget, as it is an essential item in developing the cities and countries. It is important to move people and goods from one location to another and hence to guide the economic wheel including trades, construction, industry, agriculture and tourism. It can be said that transportation is a key component of growth and globalization. "The attractiveness of particular locations depends in part on the relative accessibility, and this in turn depends on the quality and quantity of the transportation infrastructure" [3].

When planning for transportation systems, and in order to select the most appropriate modes to serve the community, the following perspectives are considered [4]:

- The individual point of view, which is the personal attitudes and perspectives.

- The policy of the community, which is the common good of the city (ex. Dubai City).

- The national efficiency (ex. UAE as overall).

Different modes of transportation are used in different cities according to city needs, technology and economy. They can be classified according to the median they use to move in; land, air, and water transport. [5-8]

In general, Marine transportation is used for different purposes including:

1- As part of public transportation system where rivers and canals are available, and in cities with good waterfronts.

2- To support road transportation systems across the rivers where the available bridges are congested.

3- Between Islands especially in cities which consist of islands or has islands with appropriate population.

4- As cheep alternative for transportation modes in poor countries where simple wooden boats are used which are run by man power.

The advantages and disadvantages of marine modes compared to other modes are summarized in Table 1 [4]. 
Table 1: The advantages and disadvantages of Marine transportation compared to other modes [4].

\begin{tabular}{|c|c|c|}
\hline Mode & Advantages & Disadvantages \\
\hline $\begin{array}{l}\text { Water } \\
\text { modes }\end{array}$ & $\begin{array}{l}\text { 1- The use of existing open channels and } \\
\text { waterways. } \\
\text { 2- Cost and efficiency since there is no need for } \\
\text { tracks and the stations can be as simple as } \\
\text { possible. } \\
\text { 3- Economical operation, thus for low speed } \\
\text { marine modes they consumes the least amount } \\
\text { of power per unit of weight. } \\
\text { 4- The safest mode with the almost lowest recorded } \\
\text { numbers of collision. } \\
\text { 5- Passenger amenities thus the trip is interesting } \\
\text { and has pleasure. } \\
\text { 6- Flexibility in changing routes and capacity. } \\
\text { 7- Resiliency thus water operation is much immune } \\
\text { to disaster events. } \\
\text { 8- High capacity for both passengers and goods. }\end{array}$ & $\begin{array}{l}\text { 1- Low speed compared to other modes. } \\
\text { 2- Poorer accessibility compared to other modes } \\
\text { if land uses surrounding the stations are not } \\
\text { properly planned. } \\
\text { 3- Weather condition is affecting the operation } \\
\text { thus storms and high tidal might stop the } \\
\text { operation. } \\
\text { 4- Wake or wash disturbance, which might erode } \\
\text { or damage the shoreline; however the new } \\
\text { technology reduces the wash effect. } \\
\text { 5- Environmental effect in case of leakage or the } \\
\text { heavy use of diesel engine with inappropriate } \\
\text { maintenance. }\end{array}$ \\
\hline
\end{tabular}

The annual public transportation trip rate per person varies in European cities between 100 and 400, and in Britain it varies between 275 and 300 . The public transportation usage might be affected in the future in UK, this is because most of the public buses users are old people who do not own cars, while most of the younger groups who form the recent working force own cars and they will continue using their cars [5]. In Germany, public transportation systems are characterized by long history and more efficient use of government subsidies, higher levels and better quality of public transportation supply, better regional integration of public transportation services, more multimodal coordination, and more favorable land use and restrictive automobile policies discouraging car use [9]. On the contrary, the modal share for private cars, in most of the US cities, is much higher since the planning of these cities was encouraging the use of private modes. The public transportation has a small modal share even with the existence of many public transportation systems within cities. This is because of the introduction of public transportation took place almost with automobiles or even after in some cities. Public Transportation in the US is limited to dense areas in large urban regions, and it is mainly for public buses with modal share of $65 \%$, and it is mainly attracting poorer residents who don't have access to a vehicle and live close to a public transportation stop [9]. Another example is Durban in South Africa, people in this city use mainly public transportation in their trips, which are mainly provided by private owners including minibuses, buses and taxis. The modal share is $80 \%$ public and only $20 \%$ private modes. The main reason for people to use public transportation here is different than European countries; it is mainly because of the cost since most of the citizens are poor and have a low income [10].

The integration of transportation modes is a new term which started to be used to define the connectivity established among different transportation systems, or modes. It has received more attention recently as a mean of improving public transportation services and reducing the reliance on private cars [11]. There is no agreed or standard definition among planners for integration, thus each group of researchers define it according to their point view or need [11]. "The complexity in defining and evaluating integration stems from the fact that it must be addressed on various levels" [12]. Some researchers divided the integration into soft, hard and institutional integration. Others define it as informative, physical integration, and tariff integration [12]. Third one define integration of public transportation (integrated transport) as a system that provides door to door public transportation services for passengers and divide it to; physical, network, fare, information and institutional integration [11]. Moreover, some of the researchers divide it as operational, and policy integration [12], and there are lots others.

The integration of different modes can be achieved at three different levels as shown in Figure 1. These three levels are:

a. City or Region level (Macro level): Multimodal Transportation Plan which needed to be in institutional level.

b. District level (Intermediate level): Multimodal transportation Plan and design.

c. Microscopic (hard or soft integration) 


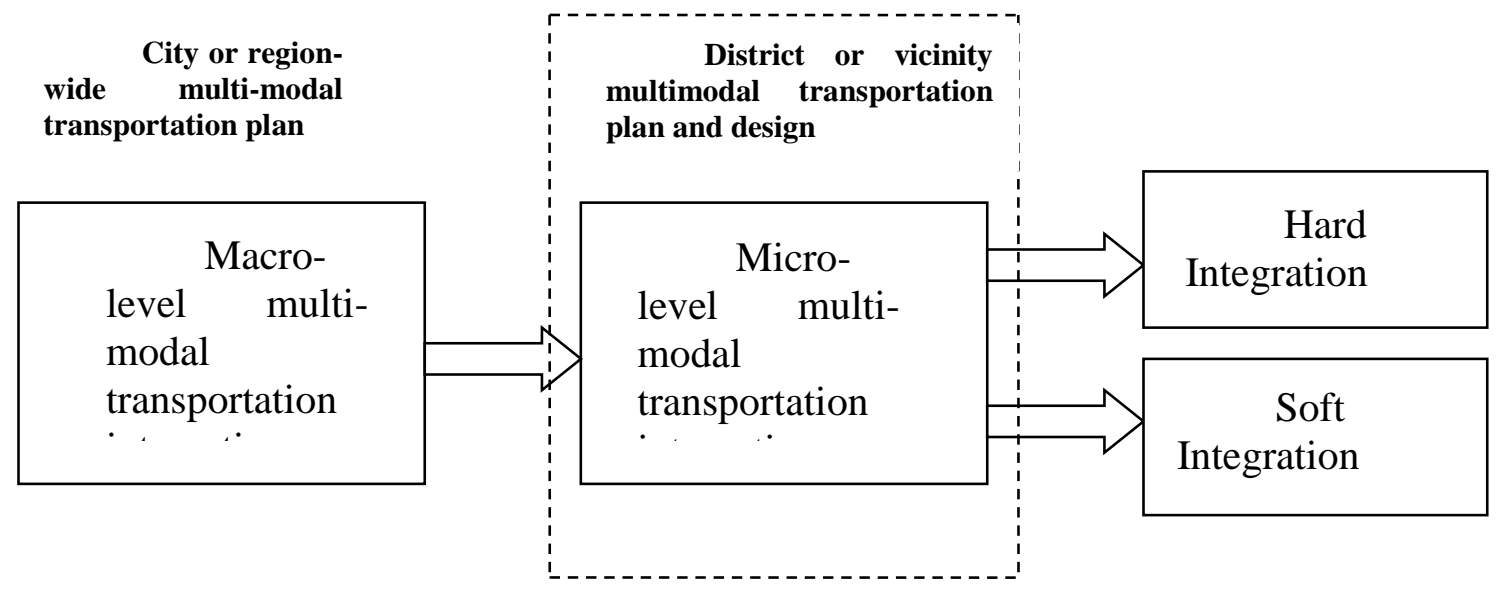

Fig. 1: Transportation Integration Levels.

Integration is an important item to achieve a successful and sustainable transportation system, which is in fact one of the main items for a sustainable community. Successful passenger-oriented intermodal transportation facilities enable easy transfers between various travel modes, which can be achieved by integration [14]. The integration level may include some items that are considered as part of the soft integration; such as fare structure, consistency of signage, maps and plans, frequency and service time tables, passenger information, and route planning and network [7, 11, 12, 14, 15]. Some other integration items are considered hard integration items, including, but no limited to: multimodal stations, walking facilities, bus stops, taxi drop areas, car parking and road access, and bicycle facilities $[10,11,15,16]$.

Several countries considered transportation integration; such as Canada, China, USA, and Thailand [17-20].

This paper considers the possible hard integration items to improve the marine transportation mode share in Dubai.

\section{Research Objectives}

The main objectives of this research are to:

1.Examine the level of hard integration provided at each case study location.

2.Identify the deficiencies in the hard integration elements at each case study location.

3.Plan appropriate integration system between Marine stations and other modes of transportation considering the limitations at each site.

4.Provide a priority list of different actions that can provide better hard integration.

\section{Methodology}

Since integration is to be implemented to many existing stations in addition to planned stations, this makes the cost of implementation relatively high and time required to be relatively long. In this case, decision makers should be able to decide on what station to be considered first and what integration tool will be the most effective one with least cost, thus they need prioritization method. For the purpose of this project, and to prioritize hard integration implementation, quantitative method has been developed which in general adopted the concept of value engineering but tailored to suit project needs. Value Engineering is a tool used usually by engineers to quantify the importance of project items in order to be able to prioritize them or to reduce project cost without affecting its quality [21]. Generally 11 items have been identified as controlling measure, these items were divided into categories and each category was given a weight as shown in Table 2. Each integration item of developed integration scheme for each station to be examined using items recorded in Table 2. 
Table 2: Controlling measures for integration items prioritization.

\begin{tabular}{|c|c|c|c|}
\hline & Controlling measures & Categories & weight \\
\hline \multirow{4}{*}{1} & \multirow[t]{4}{*}{ Cost of the solution } & Low & 4 \\
\hline & & Med & 3 \\
\hline & & High & 2 \\
\hline & & Very high & 1 \\
\hline \multirow{5}{*}{2} & \multirow{5}{*}{$\begin{array}{l}\text { Expected improvement } \\
\text { (increasing accessibility) }\end{array}$} & Attract new passenger groups & 4 \\
\hline & & Connect to major transportation station & 4 \\
\hline & & Connect to minor transportation station & 3 \\
\hline & & High improvement for private modes users & 2 \\
\hline & & Low improvement for private modes users & 1 \\
\hline \multirow{4}{*}{3} & \multirow[t]{4}{*}{ Improved Safety } & Very High & 4 \\
\hline & & High & 3 \\
\hline & & Medium & 2 \\
\hline & & Low & 1 \\
\hline \multirow[b]{2}{*}{4} & \multirow[t]{2}{*}{ Additional transfer $(\mathrm{Y} / \mathrm{N})$} & Yes & 0 \\
\hline & & No & 1 \\
\hline \multirow{4}{*}{5} & \multirow[t]{4}{*}{ Effect on transfer time } & Significant improvement & 4 \\
\hline & & Medium improvement & 3 \\
\hline & & Slight improvement & 2 \\
\hline & & No improvement & 0 \\
\hline \multirow{3}{*}{6} & \multirow[t]{3}{*}{ Effect on existing condition } & High disturbance & 1 \\
\hline & & Medium disturbance & 2 \\
\hline & & No disturbance & 3 \\
\hline \multirow{4}{*}{7} & \multirow[t]{4}{*}{ Effect on Environment } & High improvement & 4 \\
\hline & & Med improvement & 3 \\
\hline & & No improvement & 1 \\
\hline & & Negative impact & 0 \\
\hline \multirow{4}{*}{8} & \multirow[t]{4}{*}{ Effect on urban area } & High improvement & 4 \\
\hline & & Med improvement & 3 \\
\hline & & No improvement & 1 \\
\hline & & Negative impact & 0 \\
\hline \multirow{3}{*}{9} & \multirow[t]{3}{*}{ Land consumption } & High & 1 \\
\hline & & Med & 2 \\
\hline & & Law & 3 \\
\hline \multirow{3}{*}{10} & \multirow[t]{3}{*}{ People convince } & High & 3 \\
\hline & & Med & 2 \\
\hline & & Law & 1 \\
\hline \multirow{3}{*}{11} & \multirow[t]{3}{*}{ Special need access } & Available \& smooth & 3 \\
\hline & & Difficult & 2 \\
\hline & & Not available & 1 \\
\hline
\end{tabular}

After that, Table 2 is to be used for each integration item of any developed alternative and total weight for each integration item will decide on which one to have higher priority. The highest total number indicates the item has the highest priority and the lowest total number indicates the item is the least important. 


\section{Results}

This section summarizes the results of case studies of marine stations in Dubai. Most of the case studies are for existing stations which usually include water bus (WB) and Abras, where Water Taxi (WT) has been added except for Shindagha Station which is used for WB tourist route.

\subsection{Bani Yas Station}

The station lies in the CBD area and it is an open station with least facilities integrated with the surrounding landscaping and street furniture. It serves only WB and WT, and the demand is considered low. The land uses for the surrounding is commercial, leisure and offices. Lots of governmental authorities, hotels and main companies lie within the catchment area (DM, Etisalat, chamber of commerce, Sheraton hotel, Intercontinental hotel, Al Maktoom road, and others). The roads are congested most of the morning and evening peak times. Station location and the surroundings are shown in Fig. 2.

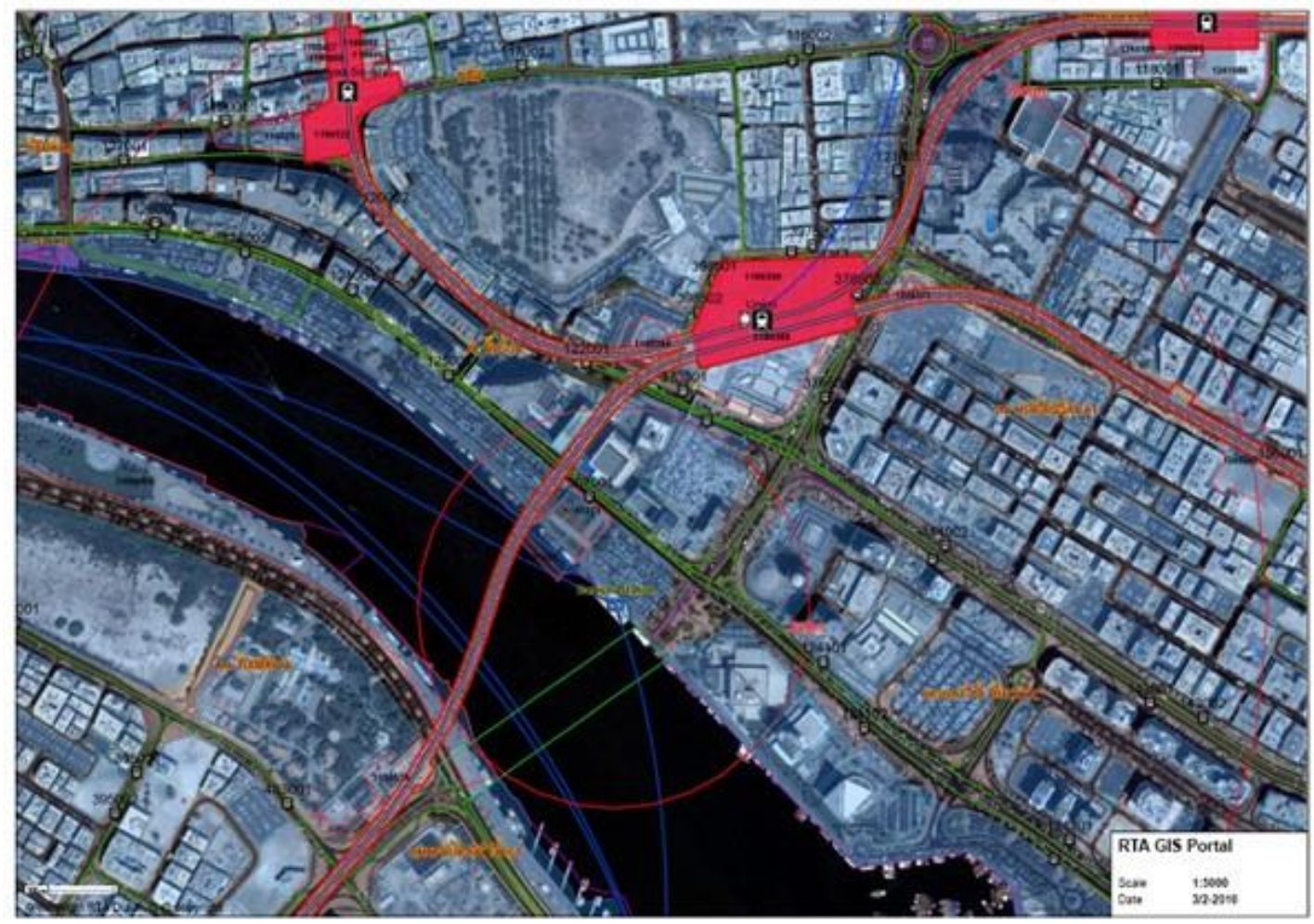

Fig. 2: Bani Yas Marine Station location, catchment area and the surroundings.

All possible integration solutions have been studied with all other modes within catchment area, and finally two integration schemes have been developed for Bani Yas Marine Station which are summarized in Table 3 and shown in Figures 3, and 4. 
Table 3: Integration alternatives for Bani Yas Station.

\begin{tabular}{|c|c|c|c|c|c|c|c|}
\hline Integration & Marine & LRT & $\mathrm{PB}$ & $\begin{array}{l}\text { Car } \\
\text { Parking }\end{array}$ & Roads & Taxi & Bicycle Facilities \\
\hline $\begin{array}{l}\text { Possible } \\
\text { Integration - } \\
1\end{array}$ & $\begin{array}{l}\text { Shade for } \\
\text { pedestrian }\end{array}$ & $\begin{array}{l}\text { Pedestrian } \\
\text { crossing/ Bridge } \\
\text { on Bani Yas Rd, + } \\
\text { convert street } 19 \\
\text { to pedestrian only } \\
\text { and provide } \\
\text { shade, and let cars } \\
\text { access to DM car } \\
\text { parking through } \\
\text { other surrounding } \\
\text { roads }\end{array}$ & $\begin{array}{lr}\text { LB1 } & \text { provide } \\
\text { shade } & \text { for } \\
\text { pedestrian } & \text { pass } \\
\text { through } & \text { car } \\
\text { parking. } \\
\text { LB2 and } \\
\begin{array}{l}\text { will use } \\
\text { integration } \\
\text { Metro }\end{array} \\
\text { raf } \\
\end{array}$ & - & $\begin{array}{l}\text { As for } \\
\text { LB1 } \\
\text { Provide } \\
\text { drop area } \\
\text { on both } \\
\text { sides with } \\
\text { safe } \\
\text { crossing }\end{array}$ & $\begin{array}{l}\text { Request } \\
\text { dedicated } \\
\text { taxis }\end{array}$ & $\begin{array}{l}\text { Add bicycle parking in } \\
\text { the station, and also in } \\
\text { the metro station. In } \\
\text { addition, bicycle track is } \\
\text { recommended in the } \\
\text { dedicated pedestrian } \\
\text { route }\end{array}$ \\
\hline $\begin{array}{l}\text { Possible } \\
\text { Integration - } \\
2\end{array}$ & As in 1 & $\begin{array}{l}\text { Provide shuttle } \\
\text { buses from LB2 } \\
\text { with clockwise } \\
\text { route and add new } \\
\text { LB on Bani Yas } \\
\text { Rd + pedestrian } \\
\text { crossing on Bani } \\
\text { Yas road }\end{array}$ & $\begin{array}{l}\text { LB1 as in } 1 \\
\text { LB3 provide } \\
\text { route connecting } \\
\text { to LB1 } \\
\text { LB2 as discussed } \\
\text { for LRT }\end{array}$ & & $\begin{array}{l}\text { As for } \\
\text { LB1 } \\
\text { Provide } \\
\text { drop area } \\
\text { on both } \\
\text { sides with } \\
\text { safe } \\
\text { crossing }\end{array}$ & As in 1 & $\begin{array}{l}\text { Add bicycle parking in } \\
\text { the station and in the } \\
\text { metro station. }\end{array}$ \\
\hline
\end{tabular}

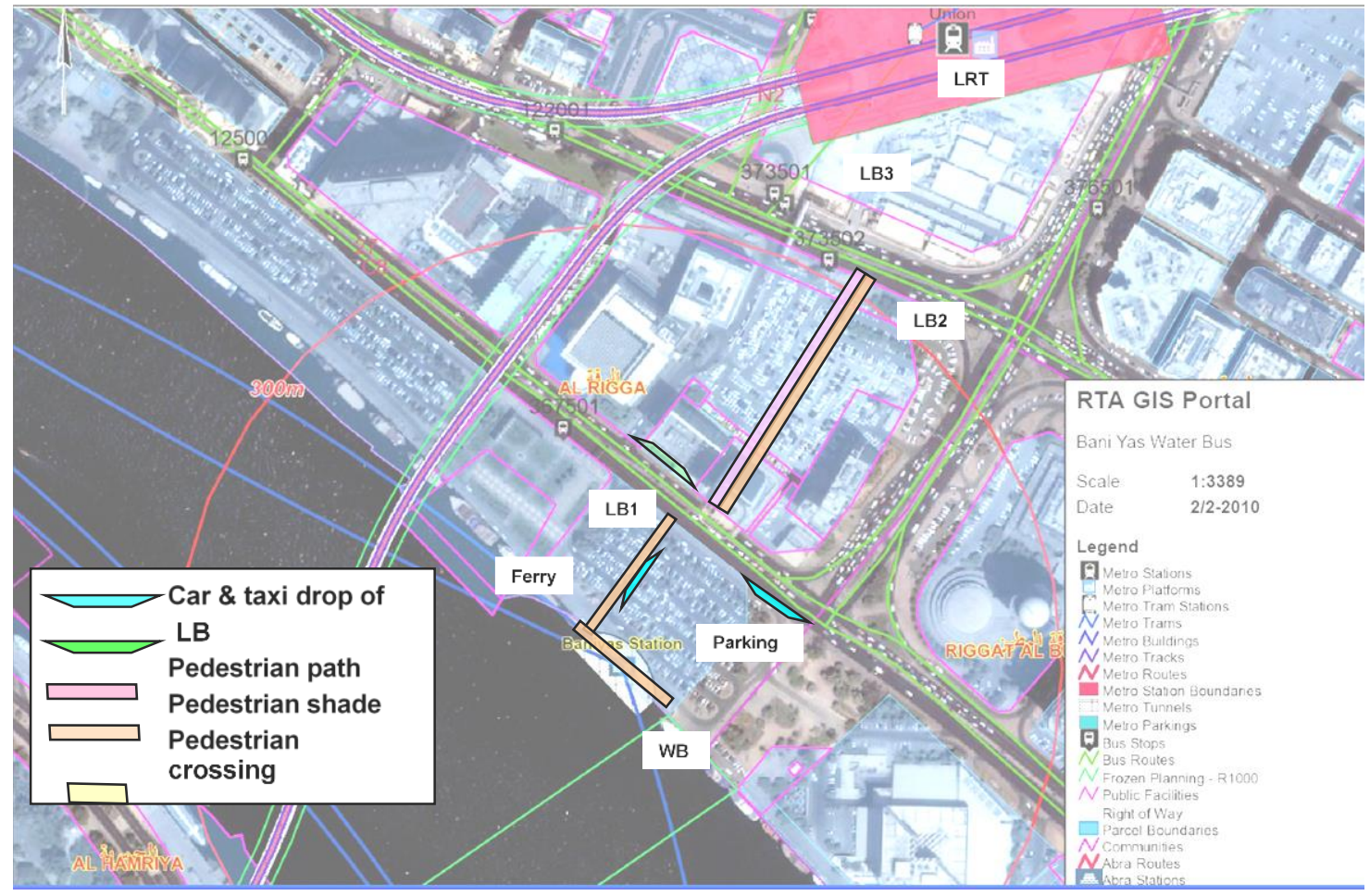

Fig. 3: Integration alternative 1. 


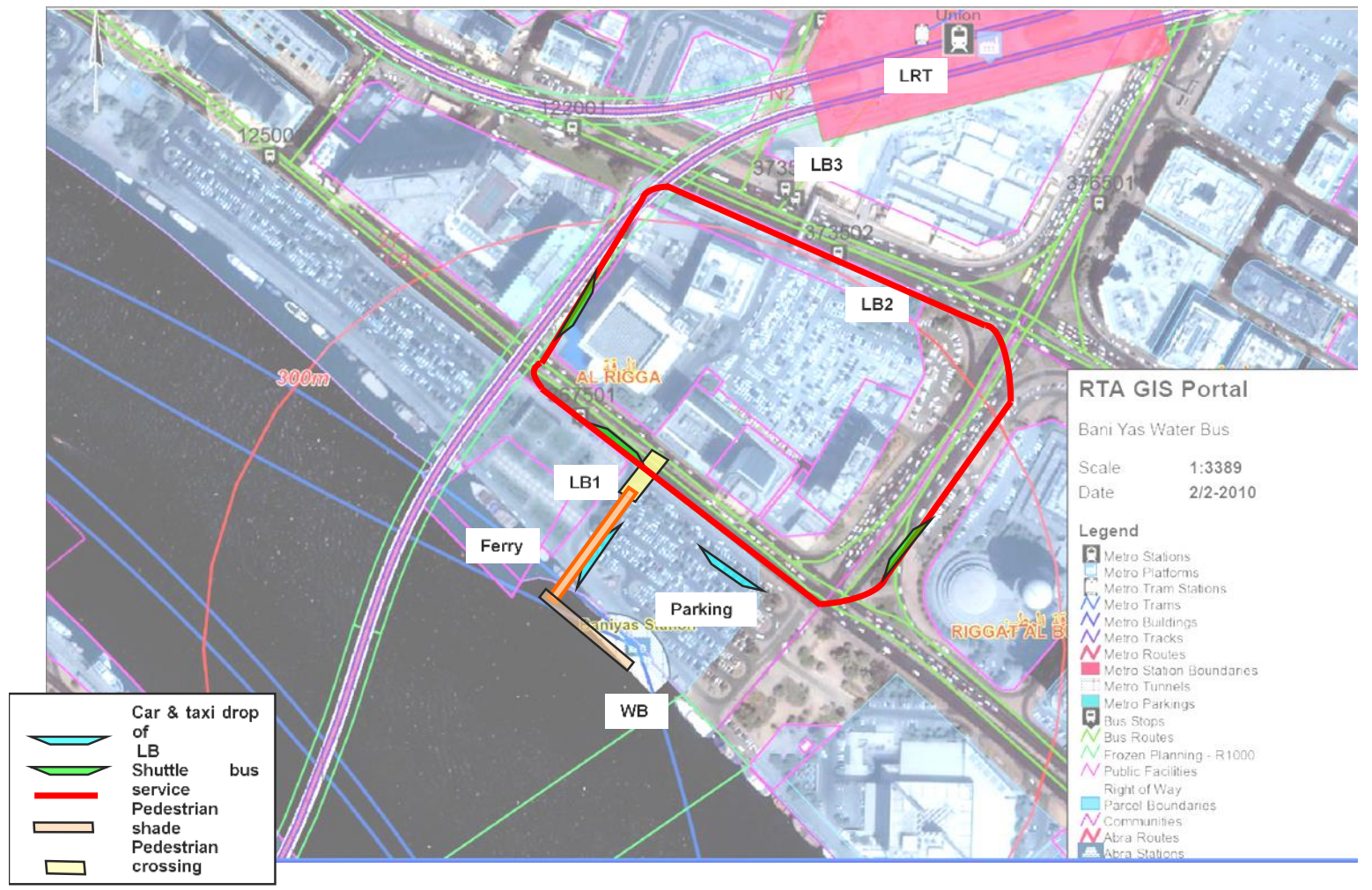

Fig. 4: Integration alternative 2.

The procedures suggested in this paper was followed and below are important notes:

1 - The catchment area has been identified by drawing 2 circles of $300 \mathrm{~m}$ and $100 \mathrm{~m}$ radius where the center was in the station.

2- Bus lay by (LB) within the catchment area has been identified where 3 existing lay by has been considered where others weren't considered since they are using the same routes while they are out of pedestrian catchment area.

3- Metro station has been considered even if it is outside the pedestrian catchment area because of its importance.

4- Other Marine station (Union Square ferry station) has been identified within pedestrian catchment area where the integration here is very important.

5- Existing integration facilities has been identified including existing pedestrian zebra crossing within signalized junctions, footpaths, and existing pedestrian bridge on Al Maktoom road. These facilities were used as part of the integration scheme.

6- Opportunity of integrating with other properties has been identified according to the importance of these properties such as DM and Etisalat.

The advantages and disadvantages of each alternative have been studied and recorded in Table 4 . 
Table 4: Advantages and disadvantages of alternative integrations.

\begin{tabular}{|c|c|c|}
\hline $\begin{array}{l}\text { Opti } \\
\text { ons }\end{array}$ & Advantages & Disadvantages \\
\hline Integration 1 & $\begin{array}{l}\text { 1- Less waiting time } \\
\text { 2- Lower operational cost } \\
\text { 3- More convenient for adults } \\
\text { 4- Will serve other users even if not } \\
\text { using the transportation modes. } \\
\text { 5- Encourage healthy practice by } \\
\text { encouraging walking }\end{array}$ & $\begin{array}{l}\text { 1- more walking distance } \\
\text { 2- higher capital cost (it might be recoverable) } \\
\text { 3- Not convenient for elderly and disabled } \\
\text { people } \\
\text { 4- More changes to the existing roads and } \\
\text { conditions }\end{array}$ \\
\hline Integration 2 & $\begin{array}{l}\text { 1- Less walking distance } \\
\text { 2- More convenient for elderly and } \\
\text { disabled people } \\
\text { 3- Reduce number of crossings to the } \\
\text { existing roads or grade changes (less } \\
\text { number of bridges, tunnels,etc) } \\
\text { 4- Lower Capital cost } \\
\text { 5- Less change to existing situation }\end{array}$ & $\begin{array}{l}\text { 1- More Waiting time (total trip time might be } \\
\text { longer) } \\
\text { 2- Higher Operational cost (which might not be } \\
\text { recoverable) } \\
\text { 3- The integration will be used only during } \\
\text { service time and other users will not benefit. } \\
\text { 4- Does not encourage walking and healthy } \\
\text { practices. }\end{array}$ \\
\hline
\end{tabular}

According to developed quantitative method, the evaluation of integration alternative 1 was done and the results recorded in Table 5.

Table 5: Evaluation of integration alternative 1 for Bani Yas Station.

\begin{tabular}{|c|c|c|c|c|c|c|c|c|c|c|c|c|}
\hline Controlling measure & 1 & 2 & 3 & 4 & 5 & 6 & 7 & 8 & 9 & 10 & 11 & Total \\
\hline Pedestrian shade & 3 & 3 & 2 & 1 & 0 & 3 & 0 & 2 & 3 & 2 & 3 & 22 \\
\hline New pedestrian Crossing & 4 & 3 & 2 & 0 & 2 & 2 & 0 & 0 & 3 & 3 & 3 & 21 \\
\hline $\begin{array}{l}\text { Change road to pedestrian. } \\
\text { footpath }\end{array}$ & 3 & 4 & 4 & 1 & 3 & 1 & 2 & 4 & 2 & 2 & 3 & 29 \\
\hline Taxi \& car drop off & 4 & 1 & 1 & 1 & 0 & 3 & 0 & 2 & 3 & 2 & 3 & 21 \\
\hline Bicycle facilities & 4 & 4 & 3 & 1 & 3 & 2 & 4 & 4 & 3 & 2 & 1 & 32 \\
\hline New bus lay-by & 4 & 3 & 2 & 0 & 3 & 3 & 0 & 0 & 3 & 3 & 3 & 24 \\
\hline
\end{tabular}

According to this evaluation, if the integration is to be implemented gradually, it should be implemented according to the following priorities:

1- Provide bicycle facilities and track, this should be implemented along with number 2 , otherwise the final grade will be different.

2- Change the road next to DM to pedestrian footpath with shade.

3- Add new bus lay-by opposite to the station on Bani Yas road.

4- Add shade to the existing pedestrian footpath.

5- Add taxi and car drop off.

It is important to know that when evaluation is done using this method, attention should be given to the overall scheme. In some cases an item can't be implemented separately without another one because it will be inappropriate, or will change the cost distribution among the items which will change the results.

\subsection{Bur Dubai Marine Station}

The station lies in the CBD area from Bur Dubai side and it is an open station with least facilities integrated with the surrounding landscaping and street furniture. It serves both WB and Abras and WT in near future but with different routes and the demand considered high for Abras. The land uses for the surrounding is commercial, residential and offices. Lots of old souqs, governmental authorities, banks, companies and small hotels lie within the catchment area. The roads are low 
capacity with very low mobility which are congested in peak times. Pedestrian movement is very high in the area especially during weekends. The following tables and figures summarize the alternative integration schemes this station. Table 6 summarizes the suggested integration. The advantages and disadvantages of each alternative were recorded in Table 7.

Table 6: Possible integration for Bur Dubai Station.

\begin{tabular}{|c|c|c|c|c|c|c|c|}
\hline Alternatives & Marine & LRT & $\mathrm{PB}$ & $\begin{array}{l}\text { Car } \\
\text { Parking }\end{array}$ & Roads & Taxi & Bicycle facilities \\
\hline $\begin{array}{l}\text { Possible } \\
\text { Integration - } 1\end{array}$ & $\begin{array}{l}\text { Clear } \\
\text { signage to } \\
\text { identify the } \\
\text { direction to } \\
\text { other } \\
\text { stations }\end{array}$ & $\begin{array}{l}\text { Add shade to } \\
\text { the existing } \\
\text { footpath + } \\
\text { pedestrian } \\
\text { crossing in } \\
\text { front of the } \\
\text { station }\end{array}$ & $\begin{array}{l}\text { Route } \\
\text { through } \\
\text { LB1 } \\
\text { could be } \\
\text { used or } \\
\text { use same } \\
\text { as for } \\
\text { LRT }\end{array}$ & $\begin{array}{l}\text { Same as } \\
\text { LRT }\end{array}$ & $\begin{array}{l}\text { Increasing } \\
\text { capacity is } \\
\text { not } \\
\text { recommend } \\
\text { ed to } \\
\text { encourage } \\
\text { Public } \\
\text { transport } \\
\text { usage. } \\
\text { Provide } \\
\text { drop of } \\
\text { area }\end{array}$ & $\begin{array}{l}\text { Provide drop } \\
\text { of and pick } \\
\text { up area. The } \\
\text { customer } \\
\text { service to } \\
\text { help the } \\
\text { passengers in } \\
\text { requesting } \\
\text { taxi. }\end{array}$ & $\begin{array}{l}\text { Provide bicycle } \\
\text { parking in the station } \\
\text { and in metro and bus } \\
\text { stations, in addition to } \\
\text { bicycle lane by } \\
\text { narrowing roadway } \\
\text { Use commercial area } \\
\text { to rend bicycles }\end{array}$ \\
\hline $\begin{array}{l}\text { Possible } \\
\text { Integration -2 }\end{array}$ & $\begin{array}{l}\text { Same as } \\
\text { option } 1\end{array}$ & $\begin{array}{l}\text { Provide new } \\
\text { internal bus } \\
\text { route to } \\
\text { connect; } \\
\text { Museum, bur } \\
\text { Dubai station, } \\
\text { Car park, } \\
\text { Metro station, } \\
\text { Public Buses } \\
\text { station, \& } \\
\text { Mina Bazar } \\
\end{array}$ & $\begin{array}{l}\text { Same as } \\
\text { for LRT } \\
+ \\
\text { additiona } \\
1 \text { LB } \\
\text { close to } \\
\text { the } \\
\text { junction } \\
\text { between } \\
\text { st. 3a \& } \\
26\end{array}$ & $\begin{array}{l}\text { Convert } \\
\text { the open } \\
\text { Car } \\
\text { parking } \\
\text { to } \\
\text { multistor } \\
\text { y car } \\
\text { parking }\end{array}$ & $\begin{array}{ll}\text { Same } & \text { as } \\
\text { option } 1 & \end{array}$ & $\begin{array}{l}\text { Same as } \\
\text { option } 1\end{array}$ & $\begin{array}{l}\text { Provide } \\
\text { parking in marine } \\
\text { station }\end{array}$ \\
\hline
\end{tabular}

Table 7: Advantages and disadvantages of the suggested integration/

\begin{tabular}{|c|c|c|}
\hline Options & Advantages & Disadvantages \\
\hline Integration 1 & $\begin{array}{l}\text { - Less waiting time } \\
\text { - Lower operational cost } \\
\text { - More convenient for adults } \\
\text { - Will serve other users even if not using the } \\
\text { transportation modes. } \\
\text { - Encourage healthy practice by encouraging } \\
\text { walking }\end{array}$ & $\begin{array}{l}\text { - more walking distance } \\
\text { - Slightly higher capital cost (it might be recoverable) } \\
\text { - Not convenient for elderly and disabled people }\end{array}$ \\
\hline
\end{tabular}

Pedestrian rate in the area is very high where the purpose is usually for shopping and leisure. The community contains lots of old souqs and attraction points such as the Museum and religious facilities. 
Similar analyses have been carried out for three more stations; namely: Dubai Old Souq Marine Station, Shindagha Marine Station (tourist), and Union Square Ferry station.

\section{Conclusions and Recommendations}

The study suggested an integration scheme for five Marine transportation stations with other modes of transportation as case studies to develop a systematic methodology to be adapted, by the Marine Agency in Dubai, to design hard integration for their existing and future marine stations. Initially, an integration item can be defined according to the existing or expected passenger flow between the considered marine station and other transportation stations as illustrated in Table 8 .

Table 8: Recommended integration method according to marine station type and passenger flow.

\begin{tabular}{|c|c|c|}
\hline $\begin{array}{l}\text { Station } \\
\text { Type }\end{array}$ & $\begin{array}{l}\text { Passenger } \\
\text { Flow }\end{array}$ & Suggested Integration Method \\
\hline $\begin{array}{l}\text { Ferry } \\
\text { station }\end{array}$ & High & $\begin{array}{ll}- & \text { Pedestrian bridge/ tunnel connecting to Metro or tram station. } \\
- & \text { Pedestrian bridge/ tunnel connecting to main attraction/ generation point ex. Shopping centre } \\
- & \text { Pedestrian footpath with shade } \\
- & \text { Bicycle facilities } \\
- & \text { Public buses shuttle service } \\
- & \text { Public buses routes } \\
- & \text { Taxi pick up area } \\
- & \text { Car passenger drop-off area } \\
- & \text { Car parking }\end{array}$ \\
\hline $\begin{array}{l}\text { WB } \\
\text { station }\end{array}$ & Medium & $\begin{array}{ll}\text { - } & \text { Pedestrian footpath with shade and environment treatment connecting to Metro or tram } \\
\text { station. } \\
\text { - } & \text { Pedestrian footpath connecting to main attraction/ generation point ex. Shopping centre } \\
- & \text { Bicycle facilities } \\
- & \text { Public buses routes } \\
- & \text { Taxi pick up area } \\
\text { - } & \text { Car passenger drop-off area } \\
- & \text { Car parking }\end{array}$ \\
\hline $\begin{array}{l}\text { WB } \\
\text { stop }\end{array}$ & $\begin{array}{l}\text { Medium to } \\
\text { low }\end{array}$ & $\begin{array}{ll}- & \text { Pedestrian footpath connecting to attraction point or leading to nearby buildings. } \\
- & \text { Bicycle facilities } \\
- & \text { Public buses routes } \\
- & \text { Taxi pick up area } \\
\text { - } & \text { Car passenger drop-off area }\end{array}$ \\
\hline $\begin{array}{l}\text { Abra } \\
\text { station }\end{array}$ & $\begin{array}{l}\text { High to } \\
\text { medium }\end{array}$ & $\begin{array}{ll}- & \text { Pedestrian footpath connecting to attraction point or leading to nearby buildings. } \\
- & \text { Bicycle facilities } \\
- & \text { Public buses routes } \\
- & \text { Taxi pick up area } \\
- & \text { Car passenger drop-off area }\end{array}$ \\
\hline $\begin{array}{l}\text { WT } \\
\text { stop }\end{array}$ & low & $\begin{array}{ll}- & \text { Pedestrian footpath connecting to attraction point or leading to nearby buildings. } \\
\text { - } & \text { Public buses routes } \\
\text { - } & \text { Car passenger drop-off area }\end{array}$ \\
\hline
\end{tabular}

In general, the implementation of hard integration in some cases needs to be prioritized and implemented in phases depending on available resources. These can be divided into 4 categories; 
a) Quick wins: These are modifications which can be applied with minimum cost and least disturbance and may lead to low and medium effects on the transportation outcomes. These modifications include; bus lay by, taxi and car drop off, bicycle parking and pedestrian crossing.

b) Medium term: These are modifications with higher cost, longer construction period and might include; footpath, pedestrian bridge or tunnel, pedestrian shade, increasing car parking and modifying access, adding turning lanes to an intersection, bicycle facilities, shuttle bus service, and new bus route.

c) Long term: These modifications in addition to the higher cost they might require approvals of stakeholders and other authorities and might include; new parking lot, multistory car park, change road planning such as changing two way to one way system, change road to pedestrian path, introduction of new bicycle lane, and major change in intersection layout.

d) Planning for future projects: when planning new projects, major transportation hubs to be proposed where all modes are connected in main stations but having different network and coverage area.

To make the process of selection more systematic, quantitative method was developed and used to evaluate the priority of each suggested integration item. The developed method was implemented for Bani Yas Station integration alternative 1 , and the results are close to the conclusion indicated above, however, the quantitative method is more realistic and shows some differences because it is implemented in a real situation which is affected by site condition and other factors.

It is important to know that when evaluation is done using this method, a great attention has to be given to the overall scheme. In some cases an item can't be implemented separately without the other one because it will be inappropriate, or will change the cost distribution among the items.

This method is a basic tool, which requires further development to be more comprehensive, where the weights to be given to each item according to the importance and further improvement is recommended as future step.

\section{Recommendations:}

The main question raising here is what is the acceptable level of service? And to how extent Dubai government is willing to pay to achieve people comfort?

To answer this question, it is important to review Dubai situation before and after financial crises. Before the financial crisis and during the economical evolution, the government and in order to attract more investment and developers, it was willing to support and subsidize the transportation as part of the infrastructure required to attract investment. Accordingly, extensive transportation infrastructure was built with the most expensive and modern technologies. In addition to capital cost, and in order to run these systems properly, these systems require high operational cost.

When the financial crisis take place, the governmental policies has been reviewed and changed toward more financial sustainability for transportation, where these systems should be able to cover its operational cost, and in some cases the capital cost. According to the existing situation, any new project or improvement should be able to cover the associated cost, and if not possible, it should be highly justifiable.

This project highly recommends that further and detailed study to be conducted to study the best practices and to recommend appropriate governmental subsidy policies which is suitable for all financial situation. On the other hand, the study should suggest other financing solutions and the new public transportation indirect revenues. Other countries best practice should be reviewed to give some guidelines but should not be ad hocked.

During the project, it was noticed that there is a lack of resources and studies regarding integration specially the hard integration. This subject is considered new and thus there is no agreed definition for it. It is highly recommended that study to be conducted covering the overall integration items. Further researches and studies are required to examine the effect of integrating transportation stations on the number of passengers and their convenience.

When studying integration in different levels, it becomes clear that proper land uses planning is an essential element that can help in the success of the integration. The traditional land uses (Pyramid zoning) to be avoided when planning cities, this is because of its negative effect on modal share by increasing dependence on private cars and make integration with transit systems difficult. It is recommended that planning authority in the city to review its land uses planning by giving more attention to public transportation, and plan mixed used communities or transit oriented development (TOD). Then new zoning would reduce the capital and operational cost of public transportation system and will allow direct integration of the stations with properties generating high trips. 
Finally, the proposed quantitative method proposed in this project used some assumed values for the weights. These weights have to be evaluated through a comprehensive study that includes detailed surveys of users, operators, and experts in order to achieve the most suitable values for these weights.

\section{References}

[1] Roads and Transport Authority, RTA-Dubai Strategic Plan 2006.

[2] F. Nunes da Silva, J. de Abreu e Sliva, "To what extent does urban density influence the modal split? The Lisbon Metropolitan Area case study," in the Proceedings of Ninth International conference on Urban Transport and the Environment in the 21st Century, WT press.

[3] D. Banister, "Transport and Urban Development," Spon Press, 1995.

[4] S. Grava, "Urban Transportation Systems - Choice for Communities," McGRAW-Hill, 2003.

[5] P. White, "Public Transport: Its Planning Management and Operation," 4th ed, Sopn Press- Taylor and rancis Group, London, UK, 2002.

[6] City of Sydney, "Sustainable Sydney 2030," City of Sydney Strategic Plan.

[7] T. Litman, "Introduction to Multi-Modal Transportation Planning - Principles and Practices," Victoria Transport Policy Institute, 2009.

[8] A. Black, "Urban Mass Transportation Planning," McGROW-Hill, 1995,

[9] R. Buehler, "Promoting Public Transportation: Comparison of Passengers and Policies in Germany and the United States," National Researcher Council, no. 2110, p 60-68, 2009.

[10] D. Allopi, "Towards an Integrated Public Transport system," in the Proceedings of Ninth International conference on Urban Transport and the Environment in the 21st Century, WT press, 2003.

[11] J. Luk, and P. Olszewski, "Integrated public transport in Singapore and Hong Kong," Road and Transport Research, vol. 12, no. 4, pp. 41-51, 2003.

[12] G. Abrate, M. Piacenza, D. Vannoni, "The Impact of Integrated Tariff systems on Public Transport Demand: Evidence from Italy," Regional Science and Urban Economics, vol. 49, pp. 120-127, 2009.

[13] S. Silsdorf, "Integrating Bicycles into Public Transportation Facilities," Boston, Massachusetts, 1-617-960-4932

[14] R. Maxwill, "Converting a Large Region to Multimodal Pulsed-Hub Public Transport Network," Transportation Research Board, no. 1835, pp. 128-136, 2003.

[15] A. Roumboutsos and S. Kapros, "A game Theory Approach to Urban Public Transport Integration Policy," Transport Policy, vol. 15, pp. 209-215, 2008.

[16] R. Vukan Vuchic, "Urban Transit - Operations, Planning, and Economic," John Wiley and Sons, INC, Hoboken, new Jersey, 2005.

[17] J. Richards, "Growth, the Winnipeg Way: Transportation Integration is the key to this growing central Canada City and its airport," Airport business, 2006.

[18] C. Kennedy, "A comparison of the Sustainability of Public and Private transportation systems; Study of the Greater Toronto Area," Kluwer Academic Publishers, vol. 29, no. 4, pp. 459-493, 2002.

[19] Z. Ying, "Integration of bicycle traffic and public transport," Hemming Group Ltd, vol. 50, no. 9, pp. 400-401, 2009.

[20] United Nations Economic and Social Commission for Asia and the Pacific (UNESCAP), "Traffic and Transportation for Sustainable Environment, Mobility and Access: Application of a Comprehensive and Integrated Approach to Policy development in the Rattanakosin Area of Bangkok," Action Plan 04, Thailand, pp. 74-79, 2001.

[21] R. Park, "Value Engineering - A Plan for Invention," CRC Press LLC, US, 1999. 